\title{
Waqf and Waste: An Unexplored Potentials
}

\author{
Muhammad Dandy Alif Wildana ${ }^{1, *}$, Asfi Manzilati
}

\author{
${ }^{1,2}$ Brawijaya University, Indonesia \\ *Corresponding author. Email: dandyalif.feb.ub@ub.ac.id
}

\begin{abstract}
Waste has become a serious problem in preserving the sustainability of the environment where humans live. Islam teaches the importance of preserving the environment as one of the efforts to preserve life. Waste management is usually under the domain of the government as part of its obligations to provide and manage public goods for the benefit of society. However, as the Covid-19 pandemic struck in late 2019, most governments globally are now short of budget and forced to take on loans to keep the economy afloat. It is worried that waste management has become a second priority in the government budget, while Covid-19 pandemic itself has produced another kind of waste that requires special handling to dispose and put more burden on the already distressing waste management issues that happened even before Covid-19. Because of the importance of preserving life as one of the parts of Iman and Islam, this paper is proposing waqf institution in its role as public goods provider to manage waste alongside the government. In short, waqf is utilized to manage waste generated so it will not harm the environment, especially during and after Covid-19 pandemic struck, potentially increasing waste generation exponentially. Moreover, it is possible for waqf institutions, either privately or publicly managed, to ease the burden of government in managing waste generated by society, from both obligation and budget perspectives. Nevertheless, the ultimate goal for this concept is to preserve the environment and life as one of the obligations stipulated in Maqasid As-Shariah (Islamic Objectives) to achieve Falah (Islamic Goal).
\end{abstract}

Keywords: Waqf, Waste, Maqasid As-Shariah, Falah.

\section{INTRODUCTION}

Waste is the result of the economic and social activities of humans. Since the rapid development of the economy posts the industrial revolution, economic activities have developed exponentially, creating a massive amount of waste in its wake. The linear economy that promotes the single-use of resources worsens the condition of waste generations which are now creating landfills in most of the world [1]. Most of the waste dumped in the landfills is not treated and can pollute the surrounding environment. This condition is becoming even more distressing since the pandemic of Covid-19 struck in late 2019 until today.

The amount of waste generated because of Covid19, especially plastic-based waste in the form of Personal Protection Equipment (PPE) such as face shields, medical masks, and other medical instruments, have increased in a staggering amount and burdens the medical waste treatment facilities. The pandemic also pushes the usage of single-use plastic as a container for food and other purposes to curb the spread of the virus that spreads rapidly through surfaces, aerosols and droplets from cough or sneeze of the infected persons according to World Health Organization (WHO). As of now, Covid-19 has infected almost 275 million people worldwide and claimed more than 5 million lives so far [2].

Based on this pressing issue, waqf is trying to step in to provide solutions on the waste management that comes from the community itself with little to no direct contribution to the government. The basis of waqf involvement is belief in Allah (tawhid), that translates into Islamic Objectives (Maqasid AsShariah) which dictates the purpose of muslim to achieve Islamic Goal (Falah) in this world and in the hereafter. In this sense, one of the aspects of Maqasid As-Shariah that waqf is trying to achieve is the preservation of nature. Preservation of nature is important, because humans only have one earth to live on, and Islam emphasize this issue seriously because human is mandated to protect and preserve nature and earth as vicegerent of Allah. 
On the other hand, this scheme is aimed to reduce the burden of government in managing waste, especially in the wake of Covid-19 pandemic that wreaks havoc on economics globally. It forces most of governments worldwide to expand their budget deficits in order to tackle Covid-19 pandemic as well as to keep the economy afloat as the result of social restriction or even lockdown to curb the spread of the virus, which further decapitate the ability of the government to handle waste management seriously, despite the increasing amount of waste. This shows the value of Islam is not limited to Muslim, but to all society because the goal of Islam is to bless everything in this world (rahmatan lil 'alamin)

\section{WASTE AND WASTE MANAGEMENT: SOME DATA TO CONSIDER}

Global waste data has shown a significant increase, and it is projected that by 2050, global waste generations will reach a staggering amount of 3.40 billion tons per year from 2.01 billion tons per year in 2016 [3]. It means that in 34 years, there will be more than $70 \%$ increase in a waste generation unless there are some measures taken to reduce the amount of waste generated. It is projected that top contributors for waste generation in 2050 come from lower-middle-income brackets, where most of the world's population are inside this bracket [3].

As for per capita waste generation, developing countries such as the United States of America and Australia are in the top position compared to other countries [3]. In terms of regions, Asia is the top waste generator, while America is in second place, with each of them generating 1.194 billion tons and 0.520 billion tons of waste respectively. The remaining region under Worldbank watch is the Middle East and Africa with a combined 303 million ton of waste.

In terms of composition of global waste, several categories dominate the waste generated, namely food and green (44\%), paper and cardboard (17\%), Other (14\%), and plastics (12\%). While the remaining portion is taken by glass $(5 \%)$, metal $(4 \%)$, rubber and leather $(2 \%)$, and wood $(2 \%)$. The data on global waste treatment and disposal, where most of the waste ended up in open dump area (33\%) and open landfill $(25 \%)$, while only $13.5 \%$ of the waste generated is disposed into recycling facilities [3].
It must be noted that the data shown by Worldbank is data on municipal solid waste, which is defined as "residential, commercial, and institutional waste". Meanwhile, Worldbank separates other types of waste and categorizes it under special waste, such as industrial, agricultural, construction and demolition, hazardous, medical, and electronic waste. Worldbank [3] registered that industrial waste generation and agriculture wastes are 18 times and 4.5 times larger than municipal waste, respectively. Construction waste is on par with solid waste, and the remaining types are only a fraction of solid municipal solid waste, but there is a high prevalence of electronic waste in high-income countries compared to the middle to low-income countries [3].

The Covid-19 pandemic worsened the condition of single-use plastic waste and medical waste classified by Worldbank as "Special Waste" that must be treated in a separate facility and disposed of carefully to not infect other people and harm other people the environment [4].[5]. There is also a substantial increase in the demand of Covid-19 plastic-based products such as gloves, masks, bottled water, food containers, and another product [6]. Furthermore, there is a surge of mismanaged plastic waste globally, amounting to 15.1 million tons, where the Asian region tops the list, with $46 \%$, followed by Europe (26\%), South America (22\%), and the other region $(6 \%)[7]$.

This increase is because governments globally follow the prescribed instructions of WHO and the Centre for Disease Prevention (CDC) for stringent physical distancing and not to reuse the PPE, and in addition, people are using more plastic because of hygiene reasons contribute to the increase of singleuse plastic [6]. Furthermore, the increase of singleuse plastic may harm the environment, especially mismanaged plastic waste that end up in the ocean, and covid-19 only exacerbates the environment's already worse condition [6],[7].

\section{WAQF: PERPETUAL ISLAMIC CHARITY}

Waqf in definition is to hold, where Muslims is encouraged to contribute some part or the entire of their wealth to waqf, and transfer the ownership to Allah and the wealth is managed by managers under the supervision of the board of trustees [8]. The role of waqf is to preserve the wealth among Muslims where the usufruct and benefit of the assets is 
enjoyed by muslim and the community in general. There are three known types of waqf, which are [8]:

1. Religious waqf: This type of waqf supports religious causes, provides facilities, and covers costs for religious services. The example for the religious waqf is for mosques, graveyards, and other religious activities.

2. Philanthropic waqf: This type of waqf is intended to support the community socially and economically. The usufruct of the asset under this type of waqf is not limited to Muslim only, but others can also enjoy it. The example for philanthropic waqf is for public utilities (roads, water sources, and other public facilities), education, protection for wildlife and environment, and capital provider for small businesses and so on.

3. Family waqf: This type of waqf was created in the era of the second caliph, Umar bin Khattab R.A. Family waqf stipulates the benefits of the waqf is to be distributed to the descendants of the giver of waqf (waqif), and if there is surplus, then it will be given to the poor and public. If there is no surviving descendant of the waqf, the estate will be taken over by the government to be managed and the usufruct will be distributed to the community.

Besides the three types of waqf, there are three main characteristics of waqf as special institutions in Islam [8] [9]:

1. Perpetuity: Assets that are contributed and declared as waqf are considered final and cannot be changed or altered in any means, unless there is some valid reasoning that makes the asset's change necessary and urgent.

2. The deeds of waqf are permanent: The deed of waqf once it is finalized cannot be changed, and every clause written in the deed must not be against shariah and must entertain the will of the waqif, and the manager of the asset must comply to the clauses in the deed.

3. The assets must be inalienable: Contributors of waqf are encouraged not to declare waqf on assets which are alienated, where it will make the waqf manager experience difficulty in accessing, managing, maintaining and distributing the usufruct of the waqf assets.

Even though the assets once declared as waqf are considered final, there is a possibility for waqf assets to be exchanged or transferred, under the conditions that the assets are not productive anymore or alienated and hard to access. This type of exchange is known as istibdal (exchange) where alienated waqf assets are either liquidated or exchanged to other assets in equal values or equal size to finance other waqf assets [10]. This practice keeps the manager of waqf efficient in managing waqf assets to broaden the impact of waqf to the community.

The impact of waqf has been studied extensively, especially in the area of socio-economic aspects of it. The main purpose of waqf is to become a panacea to the social and economic issues of society, where the government has constraints or even failed to do so $[8],[11],[12]$. The identification of the socioeconomic impact of waqf are as follows [9]:

1. Reducing government expenditure and participation in the economy

2. Preventing deficit financing and decreasing rate of interest

3. Restoring distribution of income and wealth

4. Eradicating poverty

5. Enhancing economic progress

In other studies, there are attempts to expand the influence and utilization of waqf through various venues, such as the establishment of social enterprises [13] [14] and creating social entrepreneurship based on waqf [15] [16] [17]. This attempt is to push the concept of waqf beyond the boundaries of religious, charitable, and non-profit oriented framework and promote entrepreneurship with cooperation (syirkah) between waqf institution and entrepreneur. The foundation of Islamic economy is based on partnership under profit and loss sharing scheme which is enshrined in the contract of Capital Financing (Mudarabah) and Joint Venture (Musyarakah) in order to redistribute and reallocate business resources that benefit more on the most bottom class of the society [18]. 


\section{MAQASID AS-SHARIAH AND WAQF FOR ENVIRONMENTAL PROTECTION}

Maqasid As-Shariah is an Islamic Objective that dictates aspects that must be protected and preserved which is derived from the belief (tawhid) itself [19]. Al Syathibi [19] mentioned five aspects of Maqasid As-Shariah: Protection of Religion, Protection of Self, Protection of Descendants, Protection of Ownership, and Protection of Knowledge. Furthermore, the concept of Maqasid As-Shariah is expanded by adding two more aspects, namely Protection of Social and Protection of Environment in addition to five aspects mentioned by As Syathibi. Based on Maqasid As-Shariah, the development of Kesejahteraan Semesta (C) or Universal Wellbeing is coined, as the general framework of society to achieve the desired goal, which are preserving the earth and functioning the role of human as viceregent of earth blessed by Allah, to achieve Maqasid As-Shariah, and utilizing the worldly welfare to achieve the final welfare in the hereafter [19]. Waqf, as one of the Islamic philanthropic institutions is in line with the Maqasid As-Shariah and Kesejahteraan Semesta () because the goal of waqf is the preservation of Muslim's wealth and to protect their religious, social, and economic interest. However, nowadays, the concept of waqf is expanded, not only in its role for socio-economic interests, but also into the preservation of nature, as one of the main aspects in the Maqasid As-Shariah.

The attempts of preserving nature in Islam is not a new concept. Rather, in the era of Prophet Muhammad PBUH and the Four Caliphs, the enaction of Hima (conservation area), Harim (protected area), and Ihya Al Mawat (reviving dead land) are known [20] [21] to encourage muslim to preserve the nature as the source of life and as mandated by Allah to human. Nowadays, the concept of environmental protection is greatly expanded through the involvement of instruments of Islamic Social Finance, namely zakat (mandatory alms) and waqf [22]. Most of the initiatives launched is to create a protection for the nature and environment through several actions namely the creation of forest waqf to prevent natural disaster [21], Waqf to achieve Sustainable Development Goal (SDGs) [23] [24] and to achieve socio-economic impact through forest waqf [22]. Despite all the initiatives, there is a need for a proper and established regulatory framework to achieve said goal, because protecting nature and environment is as important as protecting the human himself as stipulated in Sharia through Maqasid AsShariah [25].

\section{DISCUSSIONS: THE CONCEPT OF WAQF ON WASTE MANAGEMENT}

The concept of waqf-based waste management is applicable through two types of waqf: family waqf (family business based) or charitable waqf (public service-based). Each of the options has its own unique features and challenges on itself. In detail, the concept of waqf on waste management is explained as follows:

1. Waqf identifies required resources to set up waste management facilities such as fixed assets (land, buildings, machineries, etc.), financial assets, and expertise and combines them to set up the waste management facilities.

2. After waqf has received and combines the resources needed, it creates a special facility to receive and sort the waste into two main categories, organic and non-organic materials. As for non-organic, the waste is sorted further into recyclable and nonrecyclable, where the latter is processed further. As for hazardous waste (medical, corrosive or poisonous), waqf may cooperate with related government agencies to help dispose of the waste in a proper manner, to avoid pollution to the environment or misused.

3. After sorting the waste, the facility may proceed to the treatment of the waste based on its categories, i.e., organic or nonorganic. The organic waste such as food and other organic materials are being stored and composted inside special silo or warehouse to extract the gas and it may be distributed to houses as the replacement of Liquified Petroleum Gas (LPG) which is commonly used for home using, or the gas itself is channeled to power plant to generate electricity to power the facility and community around it. As for the remaining material of the composted organic materials, it can be repurposed as nutrient-rich soil enhancer as an alternative for chemical fertilizer.

4. For non-organic waste, the facility may process the waste received further into raw 
materials for other industries to create products based on recyclable materials, or the facilities itself can create products from recyclable materials.

5. All the proceeds received from the facilities is accumulated in the waqf is to cover the operational costs such as production, labor, maintenance, and other incurring costs that may arise from the operation of the facility.

6. If the concept of waqf is based on family $w a q f$, the profit received is entitled to the family who pledges the waqf. However, the family who set up the waqf is permitted to distribute a fraction of the profit received for public (socio-economic) or religious purposes.

7. If the concept of waqf is based on charitable waqf, all of the profit is entitled to be returned to community for public (socioeconomic) or religious purposes.

The concept of waqf on waste management conceived based on the emerging issues of global warming and climate change, where poor waste management contributes to expedite the change in the environment and ecosystem. Islam itself dictates that preservation of environment is essential and already given warning on the destruction of nature in the hands of men in the Holy Qur'an (Ar-Rum, verse 41). Another catalyst for conceiving this concept is the community's lack of awareness in terms of their waste generations. Most of the communities, especially in poor and developing countries tend not to separate the waste they generated into categories compared to communities in the developed world with better education and information access. Lastly, the government's budget constraint and lack of attention in waste management are worsening the condition, especially most of the government dumping the waste into open landfills and other remote areas that grow larger as more waste are thrown away because of increasing population in urban areas.

Besides proposing better management and handling of waste, this waqf concept is also aimed to generate profit to maintain the operation of the waqf so that the operational costs are not dependent on contributions which may be inconsistent from time to time. It is not forbidden for waqf to generate profit for non-profit purposes. This practice of profitoriented activities for non-profit purposes is also common in Western-style endowments or foundations to cover their social program costs. As for this concept, waqf may generate profits from sorting recyclable waste (plastic, metals, glass, etc.) and then sell it to factories that produce products based on recycled materials, or the facilities itself may produce products derived from recyclable materials it received and recycled.

Waqf is another opportunity to generate profit by utilizing the gas produced from decomposed organic materials. The gas itself can be channeled into houses around the facility or as fuel to generate electricity, which has become essential energy to power most modern devices. Another positive side effect from the concept is that it creates job opportunities for those who live around the facilities or people who are involved in the business, and from other businesses that support the operation of the facility. Hence, this concept is attempting to solve as many socioeconomic and environmental issues as possible

\section{CONCEPT JUSTIFICATION}

The management of waste is generally operated under the budget and jurisdiction of the local government. In some developed countries, the management of waste (usually municipal or town) is through the appointment of private institutions under a contractual basis, or in some cases the company operates based on private-oriented schemes. The concept of waqf on waste management is an attempt to give options for the community and the government and push waqf on the light of public service but based on the contributions of individuals and communities. As of now, the research on waqf is mostly based on productive waqf for poverty alleviation or other socio-economics issues [13] [14] [15] [16] [17] but only a handful of the research discuss the public function of waqf on environmental protection or enhancement [20] [21] [22] [23] [24] and almost none on waste management, as it is under the jurisdiction of government which in charge of public service duties as stipulated in constitution. This concept has its own advantages compared to current practices:

1. This concept is possible through two schemes of waqf, namely family (privately managed, and has similarity to family business) or charitable waqf (publicly managed, and responsible to society). Hence, muslim society have the option on which scheme they will choose to implement. 
2. This concept requires minimum to no contributions from the government; hence it helps by relieving some of the government's burden managing waste and even further reduces the amount of waste to be dumped into open landfills or other untreated waste facilities that may harm the environment.

3. The concept is also aimed to increase the awareness of the community on the public role of waqf institutions and the awareness of waste management through education to separate waste based on its characteristics (organic, recyclable, or hazardous).

4. This concept may also expand into creating job opportunities and green energy generations through gas produced as the byproduct of composted organic material. The energy generated may be distributed as gas for home cooking, or the gas itself could be used to generate electricity.

5. The composted organic materials may be processed further to create rich-nutrient soil for agriculture purposes and reduce chemical fertilizer that can destroy water and surrounding ecosystems in the long term.

\section{DRAWBACKS ON THE CONCEPTS}

Despite the comprehensive concept structured, some drawbacks of this concept must be addressed for the concept to materialize. There have yet to be any waqf initiatives (privately managed by family waqf or publicly under society waqf) that focus on waste management. The drawbacks of this concept are:

1. A substantial initial investment required to set up the facilities such as land, monetary resources, machineries, and expertise on waste management and electrical generation and distribution technology.

2. There has been no empirical research or feasibility studies to measure the concept's viability and economic-of-scale. This study is important because this concept has to be self-sustainable to achieve its desired goal, otherwise, it will become a catastrophic failure and waste of resources.

3. There is a possibility of friction between the waste management facility set up by waqf and government agencies responsible. Coordination and cooperation between two institutions are greatly encouraged.

4. For this concept to materialize, strong political will is needed to support the concept in the form of legislation or regulations that can be the legal basis of the initiatives set up by waqf.

5. Another issue to address is the issue of Islamic jurisprudence or Fiqh, because there will be debates on the operational and allocation of waqf resources into the management of waste. It is because there are four major branches of Islamic jurisprudence to address, and it depends on where the waqf and facilities are located, and each of the branches has different interpretations on the shariah (Islamic law) waqf.

\section{CONCLUSION}

The concept of waste management by waqf institutions is intended to push the boundaries of waqf into another dimension, and as one of the initiatives to help tackle the issues of increasing waste generations over the years, especially during and after the Covid-19 pandemic. In the past, it is known that waqf has proven as the source of private and public goods to the community, and proven its versatility. This concept proposes more involvement of the community in waste management, thus increasing the level of awareness and responsibility of the muslim community and government altogether through waqf as one of the foundations in the framework of Kesejahteraan Semesta (C). With the emergence of global warming and other environmental issues, every muslim needs to assist the government in providing solutions on the pressing environmental issues. In addition, this concept aims to ease the government's burden and enable it to shift its sources and budget to address other pressing issues. The ultimate goal of this concept is to create a better environment for people to live in a while reducing and reusing waste for other purposes, such as creating recyclable products, green energy generations, and so on. This goal is in line with one of the aspects in Maqasid As-Shariah, which is the preservation of nature/environment in order to achieve Falah in this world and in the hereafter. 


\section{REFERENCES}

[1] Worldbank [Internet]. Washington D.C: c19442019 [cited 2021 Dec 02]. Solid Waste Management. [Online]. Available: https://www.worldbank.org/en/topic/urbandevel opment/brief/solid-waste-management.

[2] John Hopkins University [Internet]. Maryland: c1876-2021 [cited 2021 Dec 02]. Covid-19 Disease. [Online]. Available: https://arcgis.com/apps/dashboards

[3] Kaza, S., Yao, L.C., Bhada-Tata, P., Van Woerden, F. [Internet]. Washington D.C: c19442018 [cited 2021 Dec 02]. What a Waste 2.0: A Global Snapshot of Solid Waste Management to 2050. [Online]. Available: https://www.openknwoledge.worldbank.org/han dle/10986/30317

[4] S. Sangkham. Face Mask and Medical Waste Disposal During the Novel COVID-19 Pandemic in Asia. Case Studies in Chemical and Environmental Engineering, vol. 2, 2020. DOI: https://doi.org/10.1016/j.cscee.2020.10052

[5] A.K. Das, Md. N. Islam., Md. M. Billah., A. Sarker. COVID-19 Pandemic and Healthcare Solid Waste Management Strategy - A Mini Review. Science of the Total Environment. vol. 778, 2021, DOI: https://doi.org/10.1016/j.scitotenv.2021.146220

[6] N.U. Benson, D.E. Bassey., Md. T. Palanisamy. COVID Pollution: Impact of COVID-19 Pandemic on Global Plastic Waste Footprint. Heliyon. vol. 7, 2021. DOI: https://doi.org/10.1016/j.heliyon.2021.e06343

[7] Y. Peng., P. Wu., A. T. Schartup., Y. Zhang. Plastic Waste Release Caused by COVID-19 and Its Fate in the Global Ocean. PNAS, vol. 118 (47). 2021, DOI: https://doi.org/10.1073/pnas.2111530118

[8] M. Kahf. The Role of Waqf in Improving the Ummah Welfare. Paper presented on the International Seminar of "Waqf as a Private Legal Body" Organized by the Islamic University of North Sumatera, Medan, Indonesia. 2003.

[9] M. A. Budiman. The Significance of Waqf for Economic Development. Munich Personal RePec Archive (MPRA), vol. 778. 2014.
Available:

https://mpra.ub.uni-

muenchen.de/81144/

[10] S.B. A. Karim. Contemporary Shari'a Compliance Structuring for the Development and Management of Waqf Assets in Singapore. Kyoto Bulletin of Islamic Area Studies, vol 3-2. 2010.

[11] M. Cizakca. Awqaf in History and Its Implications for Modern Islamic Economies. Islamic Economics Studies, vol. 6 (1), 1998; DOI: https://ssrn.com/abstract=3164811

[12] T. Kuran. The Provision of Public Goods Under Islamic Law: Origins, Impact, and Limitations of the Waqf System. Law \& Society Review, vol. $35 \quad$ (4). 2001. Available: http://www.jstor.org/stable/3185418

[13] Md. F. Mohiuddin. Islamic Social Enterprises in Bangladesh: Conceptual and Institutional Challenges. Cogent Business \& Management, vol. $4: 1, \quad 2017.2$ DOI: https://doi.org/10/1080/23311975.2017.1305674

[14] A. H. M. Noor., A. A. Sani., Z. Ab. Hasan., N. T. Misbahrudin. A Conceptual Framework for Waqf-Based Social Business from the Perspective of Maqasid Al-Shariah. International Journal of Academic Research in Business \& Social Sciences, vol. 8(8), 2018. DOI: $\quad$ https://doi.org/10.6007/IJARBSS/v8i8/4635

[15] H. Salarzehi., H. Armesh., D. Nikbin. Waqf as Social Entrepreneurship Model in Islam. International Journal of Business and Management, vol. 5 (7), 2010.

[16] W.O. Aly. Waqf Corporate Role to Enhance the Social Entrepreneurship in the Egyptian Community: Problems and Remedies. Journal of Public Administration and Governance, vol. 6 (4), 2016.2 DOI: https://doi.org/10.5296/jpag.v6i4.10504

[17] S. M. Shahriar., Md. M. Alam., J. Said., M. Monzur-E-Elahi. Waqf as a Tool for Rendering Social Welfare Services in the Social Entrepreneurship Context. Journal Al-Thaqafah. 2018; Special Issue. [Online]. Available: http://www.gjat.my/gjat2018si/S12018-06.pdf

[18] M. A. Choudhury., U. Malik. The Foundations of Islamic Political Economy. London. The Macmillan Press Ltd. 1992. 
[19] A. D. Mulawarman., A. Manzilati., A. Djalaluddin., A. Kamayanti., L. Herlambang., I. Triyuwono., et al. Kesejahteraan Semesta. Jakarta. Yayasan Rumah Peneleh. 2018.

[20] I. Ibrahim., K. p. Hua., N. A. Aziz., N. A. Hanifah. Hima as 'Living Sanctuaries': An Approach to Wetlands Conservations from the Perspective of Shari'a Law. Procedia - Social and Behavioral Sciences, pp. 105. 2013.

[21] K. M. Ali., I.S. Beik., M. Jannah., S. Kassim. The Role of Waqf Forest in the Prevention of Natural Disasters in Indonesia. BWI Working Paper Series (BWPS), vol. 2, 2021.

[22] K. M. Ali., S. Kassim., M. Jannah., Z. M. Ali. Enhancing the Role of Zakat and Waqf on Social Forestry Program in Indonesia. Economica: Jurnal Ekonomi Islam, vol. 12 (1), 2021.

DOI: https://doi.org/10.21580/economica.2021.12.1.6 $\underline{657}$
[23] S.N. Setyorini., Wirdyaningsih., C. A. Hazna. Wakaf Lingkungan Hidup dalam Rangka Pelaksanaan Pembangunan Berkelanjutan dan Penegakan Keadilan Antargenerasi. Journal of Islamic Law Studies, Sharia Journal, vol. 9, 2019.

[24] K. M. Ali., S. Kassim. Waqf Forest: How Waqf Can Play a Role in Forest Preservation and SDGs Achievement. Etikonomi: Jurnal Ekonomi, vol. 19 (2), 2020. DOI: https://doi.org/10.15408/etk.v19i2.16310

[25] M. A. 'Arafa. Islamic Policy of Environmental Conservation - 1,500 Years old - Yet Thoroughly Modern. European Journal of Law Reform, vol. 16 (2), 2014. Available: $\underline{\text { http://ssrn.com/abstract }=2514027}$ 